Raúl Alberto Cortés-Villafradez Nicolás De la Peña-Cárdenas"

Recibido: 24 de julio de 2018

Concepto de evaluación: 13 de diciembre de 2018

Aprobado: 12 de diciembre de 2019

Artículo de investigación (C) 2019 Universidad Católica de Colombia. Facultad de Ciencias

Económicas y Administrativas. Todos los derechos reservados

* Master in Organizational Management. Associate Professor (Grade II) at the School of Administration, Accounting, and Marketing of the Universidad Jorge Tadeo Lozano, Bogotá, Colombia. Email: raul.cortesv@utadeo.edu.co (D) https://orcid.org/0000-0002-1385-9186

** Master in International Affairs. Full-time Professor, Faculty of Economics and Social Sciences, Universidad de La Salle, Bogotá (Principal Affiliation). Email: ndelapena@unisalle.edu.co

(D) https://orcid.org/0000-0001-7223-9502

\section{Analysis of transport infrastructure development and competitiveness in the member countries of the Pacific Alliance (2007-2016)}

\section{ABSTRACT}

The development of transport infrastructure is a key element for increasing competitiveness, as it reduces the distance effect and freight transport costs, allowing the generation of efficiencies in market integration. This descriptive study uses a comparative methodology, taking as variables the indicators of global competitiveness of the member countries of the Pacific Alliance during the period 2007-2016. The analysis of the results shows a weak trend in the infrastructure development of the Pacific Alliance group and a notable asymmetry among the member countries. There is a need for an individual strategy in each country that is in line with the objectives of trade integration in Asia. Another finding suggests that the achievement of better indicators depends on other significant variables and on the way in which the costs of transport infrastructure investments are passed on to agents who move freight.

Keywords: Competitiveness, exports, freight cost, investment, Pacific Alliance, transport infrastructure.

JEL Classification: H54, L91, L98

Cómo citar este artículo / To reference this article / Para citar este artigo:

Cortés-Villafradez., R. A. \& De la Peña-Cárdenas. (2019). Analysis of transport infrastructure development and competitiveness in the member countries of the Pacific Alliance (2007-2016). Revista Finanzas y Política Económica, 11 (2), 277-297. doi: http:// dx.doi.org/10.14718/revfinanzpolitecon.2019.11.2.4 


\section{Análisis del desarrollo de la infraestructura de transporte y de la competitividad en los países miembros de la Alianza del Pacífico (2007-2016)}

\section{RESUMEN}

El desarrollo de la infraestructura de transporte es un elemento clave para el aumento de la competitividad, pues reduce el efecto distancia y los costos de transporte de mercancías permitiendo generar eficiencias en la integración de los mercados. Este documento realiza un estudio descriptivo con una metodología comparativa, tomando como variables indicadores de competitividad global de los países miembros de la Alianza Pacífico durante el período 2007-2016. El análisis de resultados evidencia una tendencia débil en el desarrollo de la infraestructura del grupo Alianza Pacífico y una asimetría notable entre los países miembros. Se observa la necesidad de una estrategia a nivel individual en cada país que esté acorde con los objetivos de inserción comercial a Asia. Otro hallazgo sugiere que el logro de mejores indicadores depende de otras variables significativas y de la manera como se trasladen los costos de las inversiones en infraestructura de transporte a los agentes que movilizan carga de mercancías.

Palabras clave: Alianza Pacífico, competitividad, exportaciones, fletes de transporte, infraestructura de transporte, inversión.

\section{Análise do desenvolvimento da infraestrutura de transporte e da competitividade nos países-membros da Aliança do Pacífico (2007-2016)}

\section{RESUMO}

O desenvolvimento da infraestrutura de transporte é um elemento-chave para aumentar a competitividade, pois reduz o efeito distância e os custos de transporte de mercadorias, o que permite gerar eficiências na integração dos mercados. Este artigo realiza um estudo descritivo com uma metodologia comparativa, tomando como variáveis indicadores de competitividade global dos paísesmembros da Aliança Pacífico, de 2007 a 2016. A análise dos resultados torna evidente uma fraca tendência no desenvolvimento da infraestrutura do grupo Aliança Pacífico e uma assimetria notável entre os países-membros. Observa-se a necessidade de uma estratégia no âmbito individual em cada país que esteja de acordo com os objetivos de inserção comercial na Ásia. Outro achado sugere que a conquista de melhores indicadores depende de outras variáveis significativas e da maneira como os custos dos investimentos em infraestrutura de transporte são transferidos aos agentes que mobilizam carga de mercadorias.

Palavras-chave: Aliança do Pacífico, competitividade, custo do frete, exportações, infraestrutura de transporte, investimento. 


\section{INTRODUCTION}

The main objectives of the Pacific Alliance (PA) are to increase regional integration, economic growth, and competitiveness. Therefore, in addition to achieving the flow of goods, capital, and people, it also seeks to consolidate a trade platform with an outlet to the countries of the Asia-Pacific region (Flores, 2017).

The concept of competitiveness has different theoretical perspectives that make it difficult to understand due to the quantity and complexity of the factors involved. The classic definition of competitiveness is given by Porter (2016, p. 224) as "the measure of production value per unit of labour or capital." In that sense, it equates competitiveness with productivity, but it does not reduce it to it. The purpose of competitiveness studies is to determine causes that affect it.

This research aims to develop a comparative analysis of transport infrastructure and competitiveness variables of the countries that make up the Pacific Alliance Framework Agreement. This agrement was signed in 2012 by Chile, Colombia, Mexico, and Peru and has been in force since 2014, and whose integration objective is based on the free movement of goods, services, capital, and people in order to create value chains and promote insertion in the Asia-Pacific region. The research uses a qualitative study to carry out a comparative analysis of variables. The type of tool used in the study is based on the compilation of statistical information obtained from databases on infrastructure and competitiveness of the Word Economic Forum (WEF), Infralatam, Doing Business, and Comtrade. It is important to clarify that the time series for this study are annualized and are only available from 2007 to 2016, which is why it was not possible to carry out econometric exercises. The null hypothesis of the paper is that improving transport infrastructure, through increased investment, leads to an increased competitiveness of the countries, especially when they are upgrading simultaneously, as is the case of the Pacific Alliance. Consequently, the research question is: Does increased transport infrastructure improve international integration performance in the Pacific Alliance member countries?

The paper consists of four sections. The first part presents a theoretical and conceptual framework for competitiveness, transport infrastructure, and the relationship between these two variables. The second part compares the overall competitiveness of the Pacific Alliance countries. In the third part, the transport infrastructure variables of the Pacific Alliance countries are studied. The fourth section analyzes comparative indicators of investment in transport infrastructure and their impact on competitiveness. The fifth section studies correlations between variables. Finally, the conclusions are presented.

\section{CONCEPTUAL AND THEORETICAL BACKGROUND}

Porter's Classic Theory (2016) explains national competitiveness through conditions of production, related industries, firm structure, strategy, and rivalry. For Krugman (1994), it is the capacity of a country to produce the greatest number of globally competitive goods and services, allowing thus its inhabitants to enjoy a better quality of life. In this sense, countries, like companies, compete to develop markets, attract foreign investment, develop infrastructure, and ultimately promote the wellbeing of their people (Manzur et al., 2006).

In this sense, a distinction must be made between the microeconomic and macroeconomic perspectives of competitiveness. The first aspect refers to the capacity of companies to grow, make profits, and compete, so that it is based on the price, quality, and innovation of products. Thus, a company that is more competitive than others in its sector is more likely to make a higher profit and gain a larger market share. On the other hand, competitiveness at the macro level refers to the concept of national competitiveness. In that sense, institutions, policies, and other factors are the determinants of competitiveness. However, it is important to stress 
that the two perspectives are not mutually exclusive. In fact, macro competitiveness is recognized as one that provides an adequate environment and allows the development of competitive business activities. Porter (2016) acknowledges that a nation is competitive when it has competitive firms, but these can hardly become so without the right macro environment.

Despite this classification, competitiveness must be understood as a whole in which its different levels interact. Therefore, competitiveness has a systemic perspective (Zmuda, 2017). In this sense, competitiveness has some similarities with the theory of ecological organization, since competition generates pressures for the adaptation of certain actors, while putting pressure on other species in the trophic chain to adapt to changes in these other agents (Winsor, 1998). In that order of ideas, the study of transport infrastructure and competitiveness starts from the fact that changes in the meso level (infrastructure) affect the micro level (business behavior).

However, infrastructure is defined as the set of elements, endowments or services necessary for the proper functioning of a country, a city or an organization. In this sense, countries that make greater investments in transport infrastructure through the construction of civil works on roads, railways, ports, and airports, among others, will have more possibilities for their development and will improve their competitiveness in international markets for goods and services (Kiel et al., 2014). For his part, Frischmann (2012) states that infrastructure is transversal to all sectors of the economy and has the characteristics of a public good.

The World Economic Forum (2017) defines competitiveness as the set of institutions, policies, and factors that determine a country's level of productivity. It is a construct that depends on several pillars, such as institutions, infrastructure, macroeconomic environment, health, and basic education, high level of education and skills development, efficient goods and services market, efficient labor market, financial market development, technology management, market size, business sophistication, and innovation. For the purposes of this research, competitiveness in infrastructure will be evaluated according to the Global Competitiveness Index, prepared by the World Economic Forum. This indicator consists of 12 pillars calculated based on primary sources (executive surveys) and secondary sources (international databases). All information from either primary or secondary sources was standardized on a scale of 1 to 7 , with 1 being the lowest and 7 the highest. All indices, sub-indices, and the overall score of the Global Competitiveness Report used this scale.

In this article, the evaluation of infrastructure development levels is carried out using the infrastructure pillar of the Global Competitiveness Index, which is made up of two sub-indices: on the one hand, transport infrastructure; and, on the other, electrical and communications infrastructure. The variable to be studied in greater depth in this work is transport infrastructure, which is composed of six variables: (i) overall quality of infrastructure; (ii) quality of tracks; (iii) quality of rail infrastructure; (iv) quality of port infrastructure; (v) quality of air transport infrastructure; and (vi) availability of seats on airlines.

Transport infrastructure affects competitiveness through three mechanisms. First, it stimulates international and national trade by reducing transportation times and costs (Khadaroo \& Seetanah, 2007; Zamora \& Pedraza, 2013; Gani, 2017). Second, it increases interactions between economic agents, since it allows reaching larger markets in addition to reducing the dominant position. In addition, other sectors decline, given the relocation of economic activity (Chandra \& Thompson, 2000; Gómez et al., 2016; Laird \& Venables, 2017). Third, it connects regions that previously had restricted access to transport infrastructure, which stimulates improvements in education, health, and insertion in national and international economic circuits (Kiel, Smith \& Ubbels, 2014).

Several studies have found empirical evidence that supports the theories mentioned above. For Spain (Benassi et al., 2015), Turkey (Coşar \& Demir, 2016), and the Baltic states (Mačiulis, Vasiliauskas 
\& Jakubauskas, 2009), trade flows increased as a result of infrastructure improvements. For Chile, it is found that the destruction of transport infrastructure by the 2010 earthquake resulted in the reduction of international trade. Related effects have been measured for the Colombian case, finding that transport flows affect the economic structure between urban centres (Roda et al., 2015); logistics is also evidenced as an issue that limits competitiveness in Colombia (Franco, Gómez \& Becerra, 2018). On the other hand, Duranton (2015) finds that the development of transport infrastructure in Colombia has significant effects on the exports of cities that benefit from infrastructure investments. In this regard, Yepes and Aguilar (2011) suggest promoting greater integration in the Americas, aiming to unleash cascading effects on productivity, interregional trade, and the insertion of countries into world economy. To this end, it is essential that there is an adaptation and expansion of regional, sub-regional, and national infrastructure, such as roads, railways, ports, airports, and power plants, which will have a positive effect on regional competitiveness by reducing logistics costs and attracting external investment.

According to Gutiérrez (2009), the lack of physical infrastructure aimed at economic development has been one of the most questioned elements in terms of the productive and competitive capacity of countries to face international trade, especially those in the process of development. In that sense, estimates made by Anderson and Van Wicoop (2003) suggest that the cost of transport was the third most significant expenditure in foreign trade operations, after distribution at destination and trade barriers. Therefore, variables influencing the competitiveness of international transport are the quality of transport services, execution times, roads, ports, railways and airports, and traffic (which comprises tonnes, containers, goods in general). However, distances, costs, and transport infrastructure are the factors that have the greatest impact on competitiveness, even measured by the World Economic Forum (WEF) (Zamora \& Pedraza, 2013; Çemberci, Civelek \& Canbolat, 2015).
As demonstrated, the analysis of national competitiveness leaves aside relevant factors, such as the integration of border markets; therefore, a regional approach is required (Gutiérrez et al., 2010; Purwanto et al., 2017). Recently, different projects at the national level in Colombia (such as tracks $4 G$ ), at the subregional (Pacific Alliance) as well as the regional level (such as the IIRSA project) have generated a discussion about the effects that can be expected from this. According to the Inter-American Development Bank (2014), the main objectives of infrastructure development include developing competitiveness and improving economic integration, the latter in terms of international trade.

\section{COMPARATIVE ANALYSIS OF THE OVERALL COMPETITIVENESS OF THE PACIFIC ALLIANCE COUNTRIES}

Tables 1 and 2 present information on the values and rankings of the Pacific Alliance countries for the period 2006-2016. According to the latest information available at the WEF, Chile ranked 33rd out of 152 countries with a score of 4.64. In contrast, Peru had the lowest ranking $(67 / 152)$ with a score of 4.23 . The countries most affected by the 2008 economic crisis were Chile and Mexico, while Peru and Colombia improved their scores, largely due to economic interdependence between Chile and Asia (Miranda, 2013), and Mexico and the United States (Barajas et al., 2014).

The convergence in competitiveness scores between Chile, Colombia, and Mexico is notable, especially from 2010 onwards. At the beginning of the period, the scores of these three countries ranged from 3.8 to 4.3 , while at the end of the period they were in the range of 4.2 to 4.4 (Table 1 ).

The country that has climbed the most in the ranking is Peru, from 86th in 2007 to 67th in 2016. Mexico and Colombia have been relatively stable, but the latter has improved its position since 2014, from 69 in 2013 to 61 in 2016 (Table 2).

Taken together, the average data for the Pacific Alliance countries shows that technology 
Table 1.

Values of the Global Competitiveness Index of the Pacific Alliance Countries (2007-2016)

\begin{tabular}{|c|r|r|r|r|r|r|r|r|r|r|}
\hline Country/Year & $\mathbf{2 0 0 7}$ & $\mathbf{2 0 0 8}$ & $\mathbf{2 0 0 9}$ & $\mathbf{2 0 1 0}$ & $\mathbf{2 0 1 1}$ & $\mathbf{2 0 1 2}$ & $\mathbf{2 0 1 3}$ & $\mathbf{2 0 1 4}$ & $\mathbf{2 0 1 5}$ & $\mathbf{2 0 1 6}$ \\
\hline Chile & 4.77 & 4.72 & 4.70 & 4.69 & 4.70 & 4.65 & 4.61 & 4.60 & 4.58 & 4.64 \\
\hline Colombia & 4.04 & 4.05 & 4.05 & 4.14 & 4.20 & 4.18 & 4.19 & 4.23 & 4.28 & 4.30 \\
\hline Mexico & 4.26 & 4.23 & 4.19 & 4.19 & 4.29 & 4.36 & 4.34 & 4.27 & 4.29 & 4.41 \\
\hline Peru & 3.87 & 3.95 & 4.01 & 4.11 & 4.21 & 4.28 & 4.25 & 4.24 & 4.21 & 4.23 \\
\hline
\end{tabular}

Source: Authors' elaboration based on WEF data (2017).

Table 2.

Global Competitiveness Index Ranking of the Pacific Alliance Countries (2007-2016)

\begin{tabular}{|c|c|c|c|c|c|c|c|c|c|c|}
\hline Country / Year & $\mathbf{2 0 0 7}$ & $\mathbf{2 0 0 8}$ & $\mathbf{2 0 0 9}$ & $\mathbf{2 0 1 0}$ & $\mathbf{2 0 1 1}$ & $\mathbf{2 0 1 2}$ & $\mathbf{2 0 1 3}$ & $\mathbf{2 0 1 4}$ & $\mathbf{2 0 1 5}$ & $\mathbf{2 0 1 6}$ \\
\hline Chile & 26 & 28 & 30 & 30 & 31 & 33 & 34 & 33 & 35 & 33 \\
\hline Colombia & 69 & 74 & 69 & 68 & 68 & 69 & 69 & 66 & 61 & 61 \\
\hline Mexico & 52 & 60 & 60 & 66 & 58 & 53 & 55 & 61 & 57 & 51 \\
\hline Peru & 86 & 83 & 78 & 73 & 67 & 61 & 61 & 65 & 69 & 67 \\
\hline
\end{tabular}

Source: Authors' elaboration based on WEF data (2017).

availability and infrastructure showed the largest increase in their scores, from 3.26 and 3.39, respectively, in 2007 to 3.85 and 3.8 in 2016. In contrast, the sophistication of business institutions and labour market efficiency declined in the Pacific Alliance group from 2007 to 2016.

\section{COMPARATIVE ANALYSIS OF THE PACIFIC ALLIANCE COUNTRIES' TRANSPORT INFRASTRUCTURE AND PROSPECTS}

The following is a comparative analysis of the Pacific Alliance member countries in terms of infrastructure. To this end, this section describes the current situation and analyzes competitiveness indicators by mode of transport. This is followed by an analysis of some key issues and a description of the government's plan for infrastructure development.

\section{Colombia}

The transport infrastructure in Colombia is lagging behind on roads, railways, ports, and airports, which has caused the country to position itself in this area at lower levels compared to other Latin American countries and the rest of the world (Legiscomex, 2016). In recent years, there has been a consensus on the effects in terms of competitiveness caused by the lack of adequate infrastructure in Colombia in order to accelerate sustained economic growth (through investments in the civil works construction sector) and increase multifactorial productivity.

In this sense, Colombia has recorded indicators on infrastructure quality at the global level that place it among the countries that are lagging behind the most. Such is the case of the report recently published by the World Economic Forum (WEF, 2017), which ranked the country 126th out of 144 countries in terms of road infrastructure. Figure 1 presents this information based on Colombia's score for different transport infrastructure subscripts. It shows that the best indicator is air transport, followed by ports, but roads and railways are lagging far behind.

According to Fay and Morrison (2007), fiscal, legal, and environmental problems have been delaying this investment in infrastructure, one of the most affected sectors being transport. In effect, investment in Colombia's total infrastructure in 
Indicators of Colombia's Infrastructure in 2016

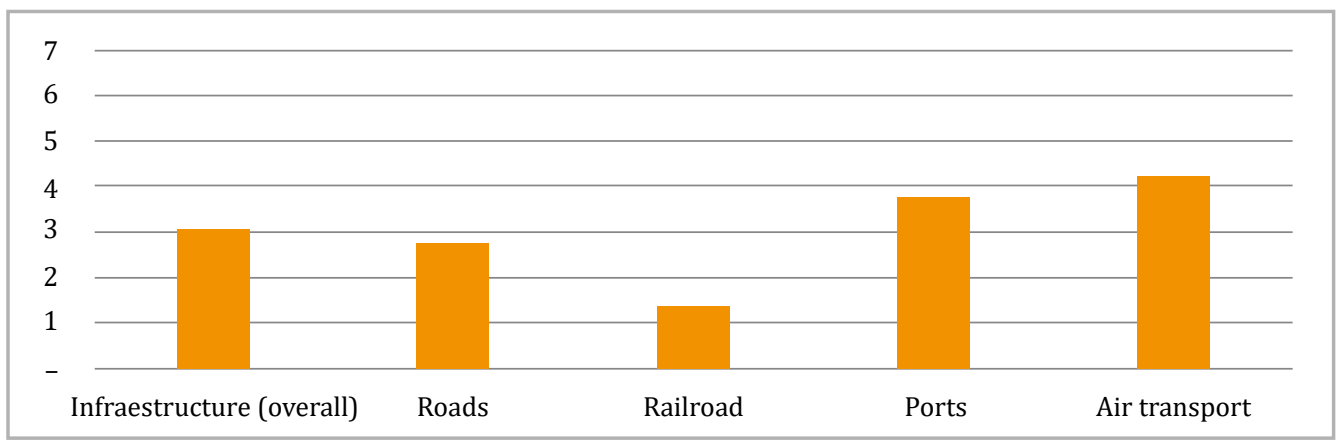

Source: Authors' elaboration based on WEF data (2017).

relation to GDP has averaged 3.2\% of GDP over the last decade, substantially below the $6 \%$ of GDP recommended by multilateral institutions, such as the IDB and the World Bank.

To address the lack of progress, the government has developed an Intermodal Transport Master Plan (PMTI, for its initials in Spanish) that has been generating the basis to create an institutional framework for the national transport sector. Likewise, the creation of the National Infrastructure Agency (ANI, for its initials in Spanish), the modernization of concession contracts, the creation of the Public-Private Partnership (PPP) Law and the Infrastructure Law, among other aspects, have brought about changes in the transportation infrastructure sector, attracting private capital investment in projects for the construction of primary roads, ports, airports, and a sample of other projects in the river and rail modes. In turn, the public sector has increased its contributions to new national projects. As a result, the sum of public and private contributions to transport tripled in a decade, from $0.89 \%$ to $2.96 \%$ of GDP between 2004 and 2014, accordint to the National Planning Department (Departamento Nacional de Planeación, 2015).

The PMTI is a commitment of the Colombian State to organize the country's growth in an efficient and strategic manner, through an infrastructure network that connects cities, regions, borders, and ports, prioritizing projects that will have the greatest impact on the national economy for the period 2015-2035. It has the following main objectives: (i) to strengthen strategic road infrastructure (4G concessions); (ii) to consolidate strategic multimodal transport corridors in rail, river, and air modes; (iii) to develop logistics infrastructure for foreign trade; (iv) to develop infrastructure for rural transformation and peacebuilding through the construction of tertiary roads and rural logistics platforms.

However, other challenges remain to be overcome, such as corruption associated with infrastructure concession systems, which have been delayed due to bribes made by foreign companies to public officials for the award of public tender contracts for civil works.

\section{Chile}

Chile is the second country in the Pacific Allianceafter Mexico-with the strongest foreign trade ( $48 \%$ of GDP), so infrastructure development is focused on supporting it, with priority given to multimodal transport connections between major 
industrial nodes and ports. In particular, rail connections and the quality of ports are remarkable.

In terms of its position in the Global Competitiveness Index, particularly the infrastructure pillar, Chile ranks 48th, only below Mexico (33). However, some particular indicators, such as road quality (30) or port infrastructure (34), place it at the top of the Pacific Alliance, as shown in Table 1. Figure 2 presents these results from the perspective of the score obtained for each indicator, which show that Chile has a relatively high quality of infrastructure, and although the score for railways is low, it is high when compared with other countries in the group.

Fluvial waterways are also an important means of transport for moving goods within the country. By 2012, more than 25 million tons were mobilized by this means, mainly mineral and fuel resources. Several ports are adapted to receive goods by river and to make the connection with the international shipping office more efficient. In comparison, Chile has more than 77,500 kilometers of road transport network, of which approximately $25 \%$ are paved. With regard to rail transport, the main company is Ferrocarril del Pacífico S.A., which was created in 1993 and has more than 1,729 kilometers of rails. It crosses the country from north to south, generating connections between large production nodes and land routes, although it also has some exits to the Pacific Ocean. The government's plans include the completion of some border roads, especially those connecting Chile with Bolivia and Argentina. Finally, with regard to air transport, there are 353 airports in the country.

To understand Chile's organization and infrastructure projects, it is necessary to take into account elements of economic geography that characterize the country. In particular, regional disparities are due to significant geographical heterogeneity and strong territorial disparities (OECD, 2017). Similarly, Chile has the highest regional inequality among OECD countries. That is why the infrastructure approach based on large industrial nodes is at the heart of government policy.

\section{Peru}

The transport infrastructure in Peru faces difficulties in terms of connection between modes of transport, since in addition to physical deficiencies in infrastructure, there are problems regarding interconnections between ports and the frequency of movement of aircrafts and ships. Consequently, freight transport costs are high and time-consuming; thus, public policy objectives are to reduce these indicators (Consejo Nacional de la Competitividad, 2014).

A review of the indicators shows that Peru ranks 98th out of 138 countries worldwide. The best performing pillar is air transport (80), while

Indicators of Chile's Infrastructure in 2016

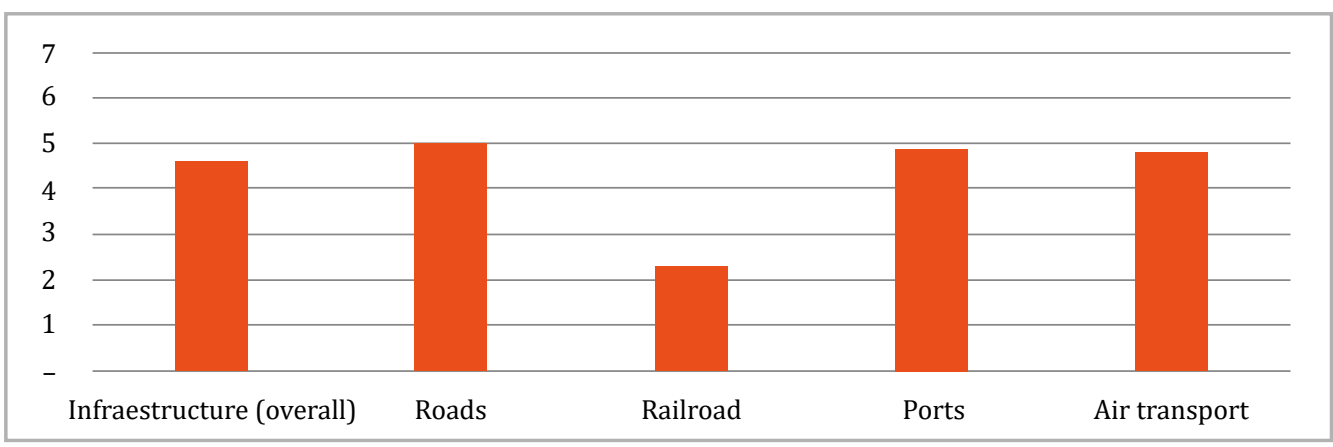

Source: Authors' elaboration based on WEF data (2017). 
the lowest is the overall quality of infrastructure (115). Figure 3 presents the perspective of the score, allowing observing the individual status of each indicator without a comparative bias.

Therefore, the lowest indicator-after railways, which are a common denominator in the region-is the overall quality of infrastructure, as evidenced by the government's improvement plans, when developing projects to improve the quality of roads and access to cargo terminals, especially seaports. Thus, comparatively speaking, Peru, together with Colombia, has the most backward competitiveness indicators of the Pacific Alliance.

In Peru, infrastructure is structured on two axes: the Pan-American North Highway and the Pan-American South Highway, which in turn connect with 22 logistics corridors distributed in the country's most important economic production and port areas. The country's entire transport network is 26,700 kilometers long, of which approximately one third was affected by environmental disasters in 2017. Although the Kuczynski government announced an investment of more than US\$ 1.3 billion for the repair, this figure is not sufficient to cover the damage and even less to carry out the work required for the 2025 plan (Oxford Business Group, 2017).

To increase competitiveness and improve integration with the Asia-Pacific region are the main objectives of transport infrastructure development in Peru, according to InvestInPeru (2016). The country initiated 31 projects worth more than
US\$ 14 billion, several of which operate through Public-Private Partnership (PPP) to improve its infrastructure. Similarly, three projects, which together total almost 3,000 kilometers, are under development within the framework of the Initiative for the Integration of the Regional Infrastructure of South America (IIRSA, for its initials in Spanish), which seeks to connect six Peruvian ports with seven Brazilian ports.

The Ministry of Transport and Communications of Peru faces similar problems to those of Colombia, especially the constant revision of tariffs and informality in the cargo transport sector (Urrunaga \& Bonifaz, 2008). Similarly, the costs of cargo transportation within the logistics operation are significantly higher than in other countries of the region, since while the average is $24 \%$, in Peru the level reaches $34 \%$, which has a negative impact on the profitability of business operations and, therefore, on the competitiveness of their products. A significant portion of cost overruns mentioned above are due to the poor multimodal connection of platforms, since less than half of them have this type of infrastructure.

In the fiscal area, according to the Asociación para el Fomento de la Infraestructura Nacional (2012), the investment gap in transport infrastructure amounts to almost US\$ 21 billion, which represents $23.8 \%$ of the outdated budget. Seeking to reduce this gap, Peru, like other countries in the region, has implemented PPPs, seeking to involve private capital and share project risk.

Figure 3.

Indicators of Peru's Infrastructure in 2016

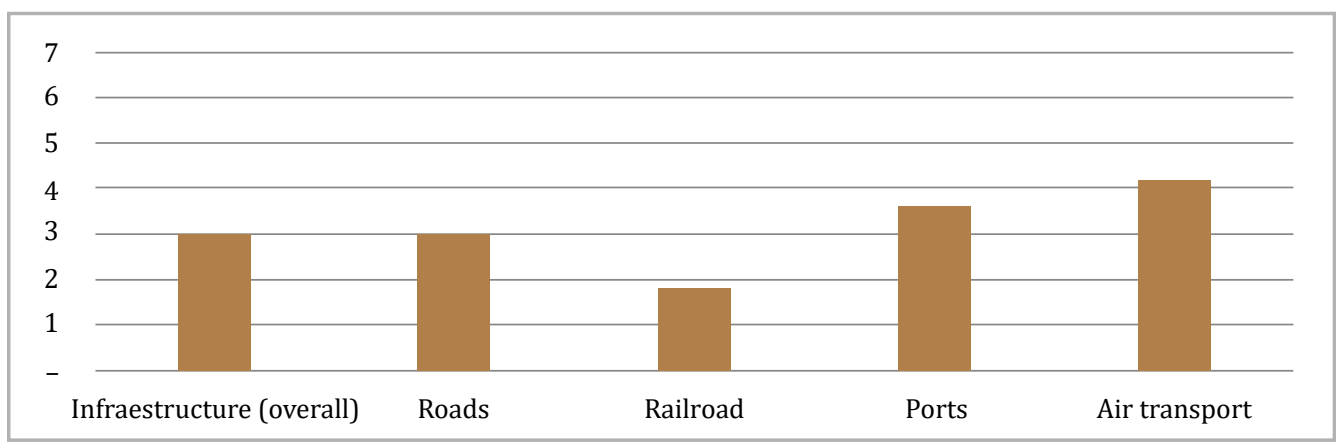

Source: Authors' elaboration based on WEF data (2017). 


\section{Mexico}

Mexico has transformed its vision of infrastructure by framing it in a broader concept called connectivity. The aim is to boost industrial production and exports. Thus, Mexico's vision is different from that of the other countries of the Pacific Alliance. This is due to a significant progress in basic connections, the overall high quality of infrastructure, and the ease of multimodal transport. The overall approach is to create a world-class infrastructure by doubling the capacity of the country's major ports, building 80 new roads, 52 highways, and 3 railways.

It is important to note that there is a marked social resistance to the development of infrastructure projects in Mexico, as some groups consider that they affect valuable resources, such as biodiversity, culture, and traditional knowledge (Flores, 2015). Similarly, one of the factors by which the country has managed to develop large projects with a certain degree of efficiency corresponds to the "opening to private investment of activities traditionally operated by state agencies," according to Bejarano (2015).

As shown in Figure 4, Mexico is the most competitive country in the Pacific Alliance, ranking 33rd in the infrastructure pillar of the World Economic Forum ranking for 2016. According to the score obtained in each subscript, as shown in Figure 9, Mexico has the most advanced railway infrastructure in the group of countries analyzed. Similarly, the overall quality of infrastructure is good, and both ports and airports score similarly high.
In order to improve connectivity, it is necessary to identify points where better connections can be developed. In this case, out of 25 border points with the United States, only eight have rail links. In terms of other infrastructure, Mexico has 102 ports, of which only four mobilize almost $96 \%$ of the cargo in containers, and 78 airports, which mobilize less than $0.01 \%$ of the total cargo (Plan Nacional de Desarrollo de México, 2012). On the other hand, it has 22,000 kilometers of railways in operation, which transport $12 \%$ of the country's cargo.

Thus, given that Mexico's exports in 2016 accounted for $74 \%$ of GDP, infrastructure is an essential asset for economic growth. Of special interest is road infrastructure, since it allows for trade with the United States, a country to which Mexico destined $81 \%$ of its exports in 2016. It is recognized that NAFTA generated significant pressures to develop infrastructure, especially in the north of the country (Islas, Hernández \& Blancas, 2004).

The current roadways total around 374,000 kilometers. A considerable extension is located in the northern part of the country, as these routes allow for trade with the United States, Mexico's main trading partner. The quality of infrastructure is remarkable, given that the Secretariat of Communications and Transport states that at least $80 \%$ is in good or acceptable condition (Plan Nacional de Desarrollo de México, 2012). Similarly, there are more than 14 corridors connecting the country's coasts, which are of crucial importance

Indicators of Mexico's Infrastructure in 2016

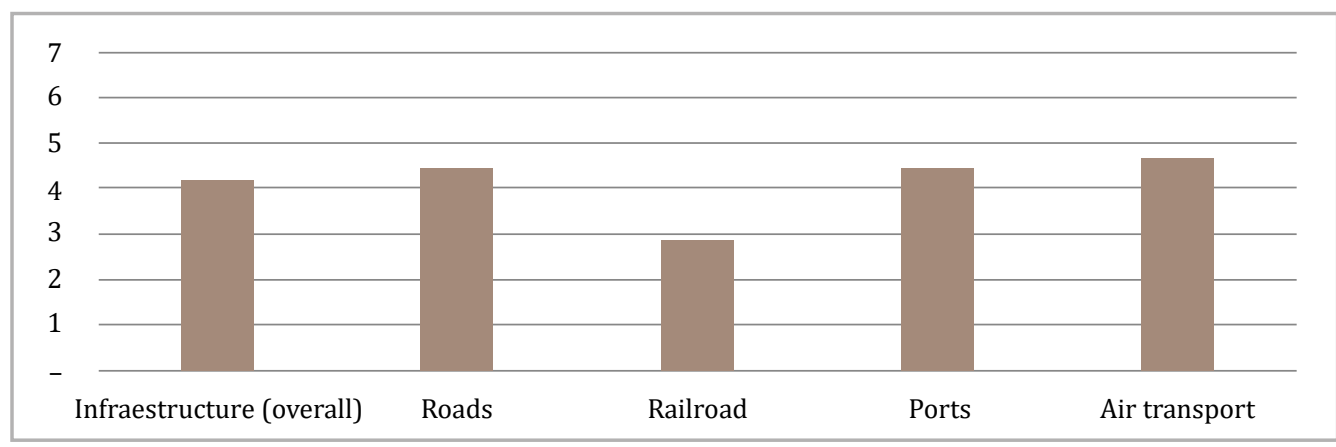

Source: Authors' elaboration based on WEF data (2017). 
since only three of them mobilize more than $45 \%$ of the country's cargo.

\section{COMPARATIVE INDICATORS OF INVESTMENT AND COMPETITIVENESS AND THEIR IMPACT}

The following is a comparative analysis of infrastructure indicators and their transformation during the period 2007-2016. First, public investment in infrastructure is analyzed. Second, quality indicators are studied for each of the transport modes. And, third, indicators of competitiveness are observed in terms of time, cost, and international trade flows.

\section{Investment and Quality Indicators}

Investment determines the level of future development of a country's infrastructure. In comparative terms, it serves as a variable to examine whether more backward countries are making efforts to close the gap. On the other hand, a review of infrastructure quality allows analyzing its impact on national and regional competitiveness.
Figure 5 shows that Colombia is the country with the highest investment in transport infrastructure with respect to GDP with 5.87\%, followed by Peru with $5.32 \%$ and Chile with 1.19\%. Mexico is the Pacific Alliance country that makes the least investment with $0.70 \%$ of its GDP.

Figure 6 shows that Chile has the best quality roads, a position the country has maintained since 2007. Mexico is in the second place, and it has increased its score the most during the period analyzed, going from 3.61 to 4.40 . On the other hand, both Colombia and Peru, which had similar scores in 2007 in terms of roads with 2.62 and 2.63 , respectively, managed to modestly improve their position, obtaining a score of 3.0 for 2016, which illustrates the backwardness of these two countries in this variable.

With regard to port quality, Figure 7 shows that the country with the highest port quality in the Pacific Alliance is Chile, despite the deterioration of this indicator, which began in 2010. Mexico is in second place with improvements in the quality of its ports, going from a score of 3.3 in 2007 to 4.3 in 2016. Although the relative positions did not change, both Colombia and Peru showed significant improvements in this indicator, increasing their scores by at least 1.10 points. Konings and Priemus

Investment in Infrastructure as Share of GDP (2008-2015)

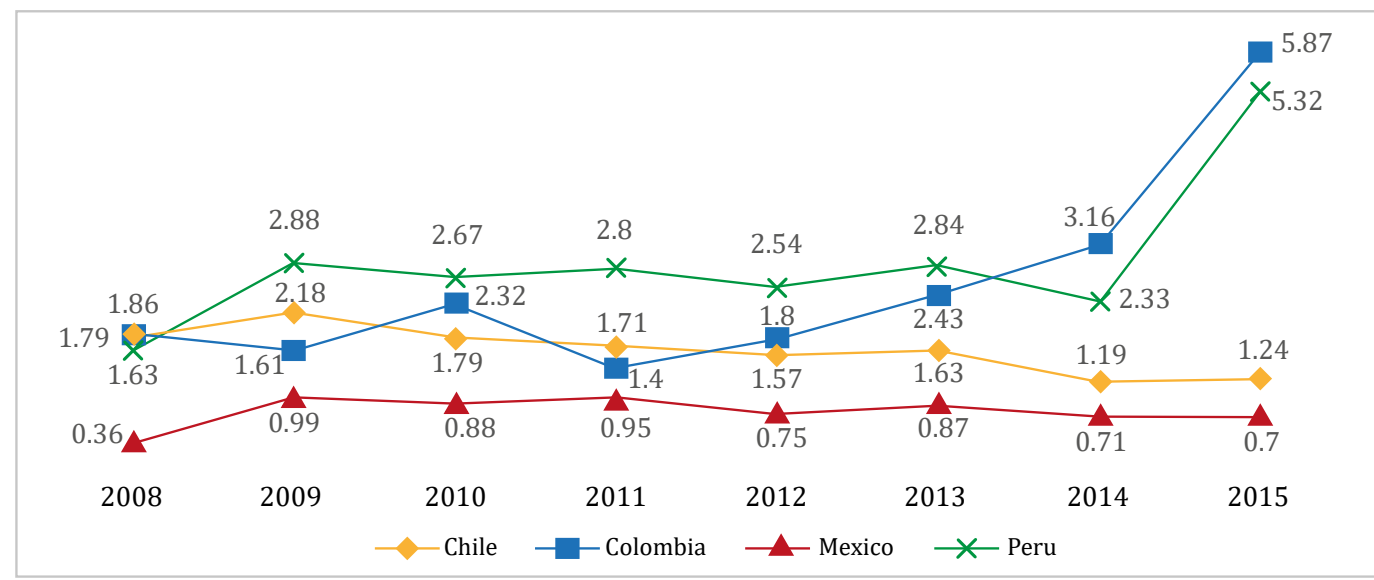

Source: Authors' elaboration based on Infralatam data (2016). 
Quality of Road Infrastructure in the Pacific Alliance Countries (2007-2016)

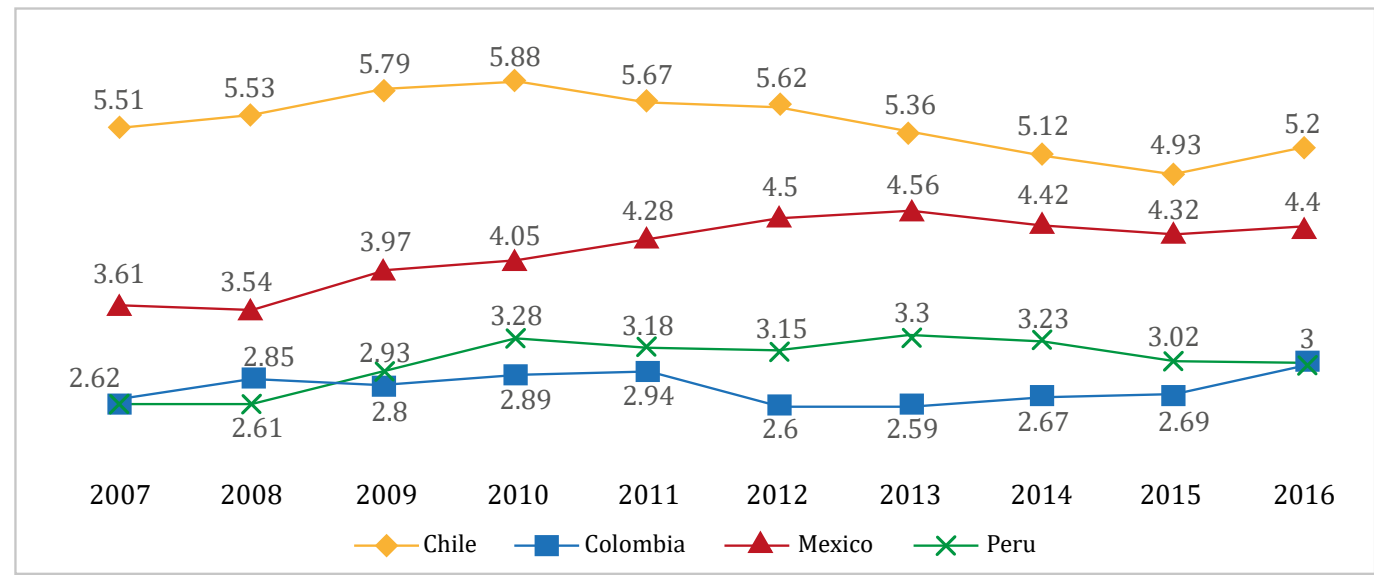

Source: Authors' elaboration based on WEF data (2017).

Figure 7.

Quality of Port Infrastructure in the Pacific Alliance Countries (2007-2016)

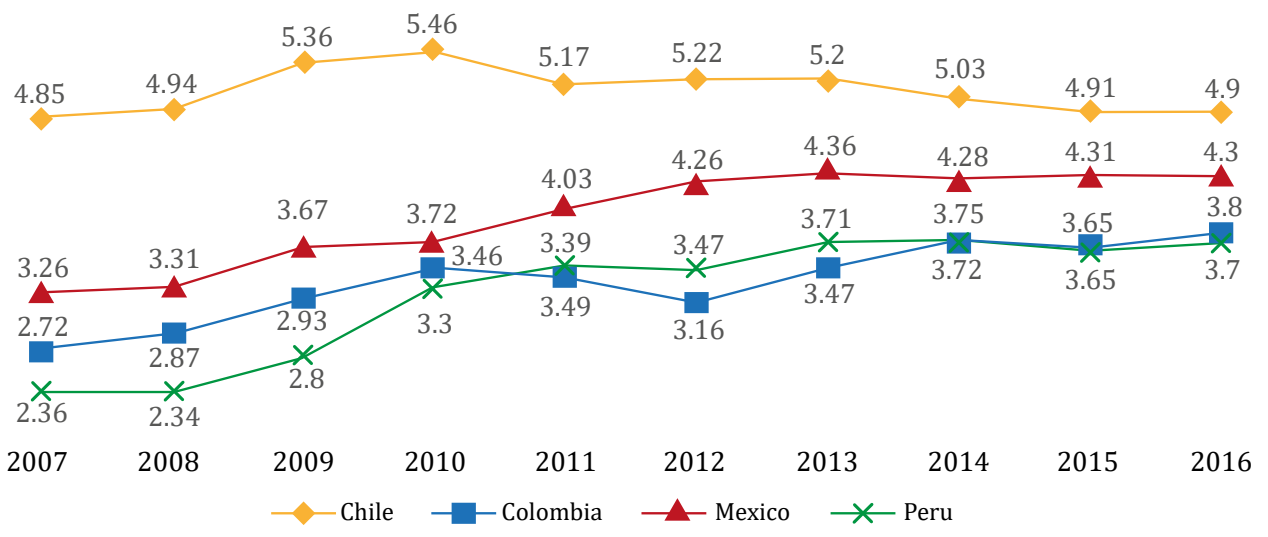

Source: Authors' elaboration based on WEF data (2017).

(2014) highlight the importance of improving port infrastructure, since the concentration of shipping companies and an increased bargaining power have made the sector more rigid, affecting small companies that do not have the capacity to negotiate; therefore, improving efficiency in time and cost of port infrastructure contributes to reducing this barrier.

In terms of air transport infrastructure quality, there is a trend towards convergence in the Pacific Alliance countries. Chile leads with a score of 4.5, followed by Mexico with 4.4; the third place is contested by Peru and Colombia with 4.1. It is evident how this indicator has been deteriorating in both Chile and Mexico since 2011. Finally, Colombia's recovery in this indicator since 2012 is noteworthy.

As Figure 9 shows, all Pacific Alliance countries have low indicators of rail transport quality. Chile is the leader in quality rail infrastructure with a score of 2.8, followed by Mexico with 2.5. Colombia 
Quality of Air Infrastructure in the Pacific Alliance Countries (2007-2016)

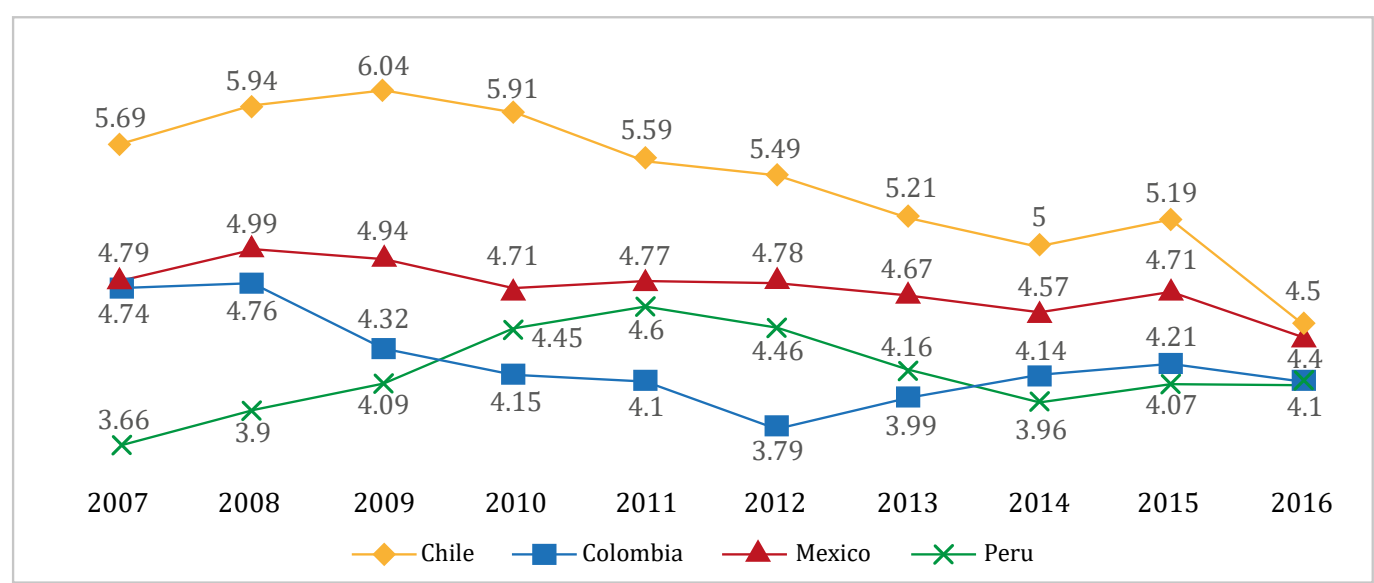

Source: Authors' elaboration based on WEF data (2017).

Figure 9.

Quality of Railroad Infrastructure in the Pacific Alliance Countries (2009-2016)

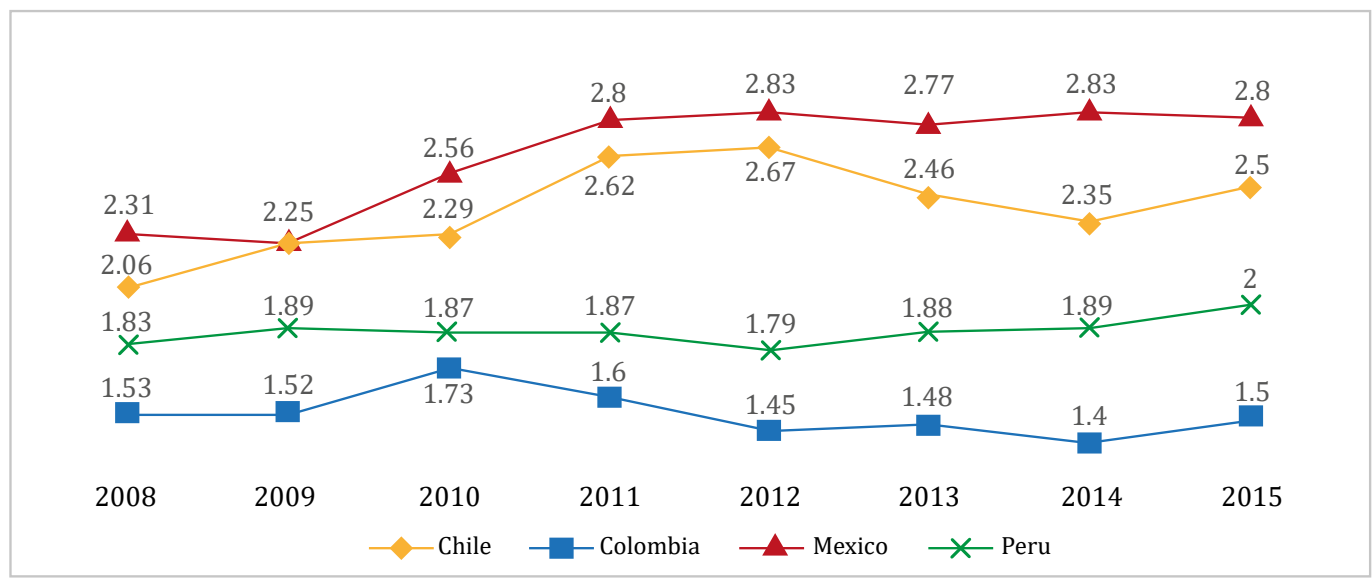

Source: Authors' elaboration based on WEF data (2017).

has the lowest indicator with 1.5 , and this has been constant during the period under review.

Overall, the quality of infrastructure in the Pacific Alliance countries is good in air transport, but there are marked disparities between Chile and Mexico, and Peru and Colombia. The lags are evident for all countries in rail infrastructure. According to Bąk (2016), this type of infrastructure is the one that presents the best relationship between investment and improvement in competitiveness, especially for companies involved in international trade.

\section{Competitiveness Indicators}

In addition to quality indicators, analyzing times and costs allow observing the impact of transport infrastructure on competitiveness. To the effect, cost per container and the time to carry out an international trade operations are analyzed from the point of view of imports and exports.

As shown in Table 3, Peru and Mexico are the countries with the lowest export time of 12 days, followed by Colombia with 14 days, and finally 
Table 3.

Time (Days) to Export in the Pacific Alliance Countries (2007-2015)

\begin{tabular}{|c|c|c|c|c|c|c|c|c|c|c|}
\hline Country/year & $\mathbf{2 0 0 7}$ & $\mathbf{2 0 0 8}$ & $\mathbf{2 0 0 9}$ & $\mathbf{2 0 1 0}$ & $\mathbf{2 0 1 1}$ & $\mathbf{2 0 1 2}$ & $\mathbf{2 0 1 3}$ & $\mathbf{2 0 1 4}$ & $\mathbf{2 0 1 5}$ & Var \% 2007-2015 \\
\hline Chile & 17 & 17 & 17 & 17 & 17 & 17 & 15 & 15 & 15 & -11.76 \\
\hline Colombia & 34 & 24 & 14 & 14 & 14 & 14 & 14 & 14 & 14 & -58.82 \\
\hline Mexico & 13 & 13 & 13 & 13 & 12 & 12 & 12 & 12 & 12 & -7.69 \\
\hline Peru & 22 & 22 & 22 & 21 & 12 & 12 & 12 & 12 & 12 & -45.45 \\
\hline
\end{tabular}

Source: Authors' elaboration based on Doing Business data (2016).

Chile with 15 days. The country with the best progress in this area during the period analyzed was Colombia with a 58.8\% reduction in export times, followed by Peru with a 45.4\% reduction in costs.

According to Table 4, Peru has the lowest export cost with US\$ 890, with the highest increase of all Pacific Alliance countries in the 2007-2015 period with $54.8 \%$. In second place, Chile has an export cost of US\$ 910, with an increase of $41.09 \%$ in its value. Thirdly, there is Mexico with US\$1,499, and finally, Colombia is the Pacific Alliance country with the highest export costs with US\$2,355.

Table 5 shows that Mexico is the country with the lowest time to import goods with 11.2 days, followed by Chile with 12 days, Colombia with 13 days, and finally Peru with 17 days.
Table 6 shows that Chile has the lowest import costs, with US\$ 860, however, it presented an increase of $43.3 \%$ during the period 2007-2015. Peru is in the second place, with a cost of US\$1,010 and an increase of $50.75 \%$ in its costs. Mexico has costs of US\$1,888, and finally Colombia is the least competitive Pacific Alliance economy in this area with an import cost of US\$2,470.

\section{International Trade Indicators}

Infrastructure and competitiveness are linked to export performance, since exports are sensitive to transport costs and times (Limão \& Venables, 2001). For an analysis of the Pacific Alliance countries, it should be made clear that the main exports of

Table 4

Export Cost (US\$ per Container) in the Pacific Alliance Countries (2007-2015)

\begin{tabular}{|c|c|c|c|c|c|c|c|c|c|c|}
\hline Country / Year & $\mathbf{2 0 0 7}$ & $\mathbf{2 0 0 8}$ & $\mathbf{2 0 0 9}$ & $\mathbf{2 0 1 0}$ & $\mathbf{2 0 1 1}$ & $\mathbf{2 0 1 2}$ & $\mathbf{2 0 1 3}$ & $\mathbf{2 0 1 4}$ & $\mathbf{2 0 1 5}$ & Var \% 2007-2015 \\
\hline Chile & 645 & 645 & 745 & 745 & 745 & 795 & 980 & 980 & 910 & 41.09 \\
\hline Colombia & 1,845 & 1,540 & 1,790 & 1,870 & 1,870 & 2,370 & 2,355 & 2,355 & 2,355 & 27.64 \\
\hline Mexico & 1,302 & 1,302 & 1,472 & 1,472 & 1,420 & 1,450 & 1,450 & 1,499 & 1,499 & 15.15 \\
\hline Peru & 575 & 575 & 860 & 860 & 860 & 860 & 890 & 890 & 890 & 54.78 \\
\hline
\end{tabular}

Source: Authors' elaboration based on Doing Business data (2016).

Table 5.

Time (Days) to Import in the Pacific Alliance Countries (2007-2015)

\begin{tabular}{|c|c|c|c|c|c|c|c|c|c|c|}
\hline Country / Year & $\mathbf{2 0 0 7}$ & $\mathbf{2 0 0 8}$ & $\mathbf{2 0 0 9}$ & $\mathbf{2 0 1 0}$ & $\mathbf{2 0 1 1}$ & $\mathbf{2 0 1 2}$ & $\mathbf{2 0 1 3}$ & $\mathbf{2 0 1 4}$ & $\mathbf{2 0 1 5}$ & Var \% 2007-2015 \\
\hline Chile & 16 & 16 & 16 & 16 & 16 & 15 & 12 & 12 & 12 & -25.00 \\
\hline Colombia & 35 & 20 & 15 & 14 & 13 & 13 & 13 & 13 & 13 & -62.86 \\
\hline Mexico & 17 & 17 & 17 & 17 & 12 & 12 & 12 & 11.2 & 11.2 & -34.12 \\
\hline Peru & 29 & 29 & 25 & 24 & 17 & 17 & 17 & 17 & 17 & -41.38 \\
\hline
\end{tabular}

Source: Authors' elaboration based on Doing Business data (2016). 
Table 6.

Import Cost (US\$ per container) in the Pacific Alliance Countries (2007-2015)

\begin{tabular}{|c|c|c|c|c|c|c|c|c|c|c|}
\hline Country / Year & $\mathbf{2 0 0 7}$ & $\mathbf{2 0 0 8}$ & $\mathbf{2 0 0 9}$ & $\mathbf{2 0 1 0}$ & $\mathbf{2 0 1 1}$ & $\mathbf{2 0 1 2}$ & $\mathbf{2 0 1 3}$ & $\mathbf{2 0 1 4}$ & $\mathbf{2 0 1 5}$ & Var \% 2007-2015 \\
\hline Chile & 600 & 600 & 710 & 710 & 710 & 760 & 930 & 930 & 860 & 43.33 \\
\hline Colombia & 1,773 & 1,440 & 1,640 & 1,750 & 1,700 & 2,650 & 2,650 & 2,470 & 2,470 & 39.31 \\
\hline Mexico & 1,761 & 1,761 & 2,050 & 2,050 & 1,880 & 1,780 & 1,780 & 1,805 & 1,888 & 7.19 \\
\hline Peru & 670 & 670 & 895 & 895 & 880 & 880 & 880 & 1,010 & 1,010 & 50.75 \\
\hline
\end{tabular}

Source: Authors' elaboration based on Doing Business data (2016).

Table 7.

Exports from the Pacific Alliance (Without Major Minerals) to the Pacific Alliance (2007-2016)

\begin{tabular}{|c|c|c|c|c|c|c|c|c|c|c|c|}
\hline Country/ Year & $\mathbf{2 0 0 7}$ & $\mathbf{2 0 0 8}$ & $\mathbf{2 0 0 9}$ & $\mathbf{2 0 1 0}$ & $\mathbf{2 0 1 1}$ & $\mathbf{2 0 1 2}$ & $\mathbf{2 0 1 3}$ & $\mathbf{2 0 1 4}$ & $\mathbf{2 0 1 5}$ & $\mathbf{2 0 1 6}$ & Var \% 2007-2016 \\
\hline Chile & 3.015 & 3.578 & 2.773 & 3.222 & 3.855 & 3.736 & 3.740 & 3.827 & 3.497 & 3.248 & $8 \%$ \\
\hline Colombia & 1.465 & 1.538 & 1.485 & 1.842 & 2.230 & 2.384 & 2.336 & 2.254 & 2.259 & 2.166 & $48 \%$ \\
\hline Mexico & 4.785 & 5.751 & 4.089 & 6.539 & 8.519 & 8.421 & 8.112 & 8.436 & 6.809 & 5.926 & $24 \%$ \\
\hline Peru & 992 & 1.258 & 982 & 1.289 & 1.740 & 1.827 & 1.835 & 1.807 & 1.572 & 1.494 & $51 \%$ \\
\hline
\end{tabular}

Source: Authors' elaboration based on Comtrade. Values in millions of dollars.

these countries-except for Mexico-are natural resources, which maintain a behavior independent of the state of transport infrastructure. Therefore, some of the main tariff chapters corresponding to the main minerals exported are excluded.

Table 7 shows that the results of exports within the Pacific Alliance block have been positive during the period under review. Diversification has also increased, especially at the industrial level for all the countries analyzed.

On the other hand, Table 8 shows positive results for all members, except for Colombia. This is consistent with the above results that show a reduction in export times and costs, although these are also influenced by a decrease in regulations and procedures.

\section{STUDY OF CORRELATIONS}

The correlation result between investment as a percentage of GDP and export costs to Colombia, Peru, and Mexico is positive (but not very significant) suggesting that greater investment in infrastructure increases the costs of exports. This fact can be explained by higher compensation rates and tolls to pay off the largest systems investment.

Table 8.

Exports of the Pacific Alliance (Without Major Minerals) to the World (2007-2016)

\begin{tabular}{|c|c|c|c|c|c|c|c|c|c|c|c|}
\hline Country/Year & $\mathbf{2 0 0 7}$ & $\mathbf{2 0 0 8}$ & $\mathbf{2 0 0 9}$ & $\mathbf{2 0 1 0}$ & $\mathbf{2 0 1 1}$ & $\mathbf{2 0 1 2}$ & $\mathbf{2 0 1 3}$ & $\mathbf{2 0 1 4}$ & $\mathbf{2 0 1 5}$ & $\mathbf{2 0 1 6}$ & $\begin{array}{c}\text { Var \% 2007- } \\
\mathbf{2 0 1 6}\end{array}$ \\
\hline Chile & 25.017 & 29.111 & 23.668 & 26.651 & 32.894 & 32.746 & 33.840 & 34.762 & 30.135 & 30.486 & $22 \%$ \\
\hline Colombia & 19.119 & 20.331 & 17.072 & 17.255 & 20.464 & 20.656 & 19.543 & 18.857 & 16.830 & 16.294 & $-15 \%$ \\
\hline Mexico & 229.224 & 241.100 & 199.211 & 257.234 & 293.626 & 318.542 & 331.269 & 355.309 & 358.020 & 355.776 & $55 \%$ \\
\hline Peru & 13.723 & 16.685 & 15.689 & 19.085 & 24.932 & 24.846 & 22.835 & 20.731 & 18.990 & 19.758 & $44 \%$ \\
\hline
\end{tabular}

Source: Authors' elaboration based on Comtrade. Values in millions of dollars. 
In the case of Chile, it is the opposite and suggests that a decrease in investment leads to greater costs of export. When observing the correlation between investment in infrastructure (as a percentage of GDP) and time (days) to export, it is found that in the countries that have made the most investment, time has decreased, suggesting that investments have had a positive impact. The case of Chile stands out, since the correlation is strong and positive (0.74). The explanation is that Chile has reduced its investment while the time to export has also been reduced slightly.

The correlation result between the quality of ports and the cost of exports is positive for all countries, but its effect is more significant in the case of Peru and Mexico. However, in terms of days, the effect is the most relevant. In the case of Colombia, Mexico, and Peru, the correlation is strong (in all cases exceeding -0.82), which suggests that improving the quality of ports has a significant impact on the reduction of days to export and, therefore, on competitiveness.

The correlation result between the quality of roads and the cost of exports is positive for both Mexico and Peru. For Colombia and Chile, the results suggest that an improvement in the quality of roads reduces export costs. The effect on the reduction of export time is more moderate than in the case of port infrastructure. In Colombia, the effect is minimal; in Peru, it is moderate and in Mexico, it is significant.

The correlation result between the quality of airports and export cost is reverse for Chile, Colombia, and Mexico, which suggests that an improvement in the quality of airports reduces export costs. For Peru, the result is the opposite and reveals that the improvement of this indicator leads to higher export costs. Given that in Colombia, Mexico, and Chile the quality of airports has deteriorated and the time to export has been reduced, the correlation is positive. However, it is pertinent to clarify that this result is because most of the exports are made by sea, so that the effect of airport infrastructure is not seen in the correlations.
The correlation result between the quality of roads and the cost and time of imports for Chile, Colombia, and Mexico suggests that lower quality of roads generate an increase in export costs. In the case of Peru, the result shows otherwise. The correlation result between investment as a percentage of GDP and the cost of imports for Colombia, Peru, and Mexico evidences positive correlations suggesting that an increased investment in infrastructure raises the costs of export. In the case of Chile, it is the opposite and it suggests that a decrease in investment leads to greater costs of export. From the perspective of time, an improvement in the quality of roads is related to a decrease in days to import, particularly in the case of Mexico and Peru.

The correlation result between the quality of ports and the cost of imports is positive for Chile, Colombia, and Peru, but its effect is more meaningful in the last country, which indicates that an improvement in the quality of ports leads to higher import costs. On the contrary, a better quality of ports is associated with shorter times to import, finding a significant effect for Colombia, Mexico, and Peru.

The correlation result between investment as a percentage of GDP and exports within the Pacific Alliance is positive (but not very significant) for Colombia and Mexico, suggesting that greater investment in infrastructure increases intra-Alliance exports. In the case of Chile, this result is objected, suggesting that a decrease in investment leads to increased exports. In the case of Peru, the correlation is null.

The correlation result between the quality of ports and exports within the Pacific Alliance is positive for Colombia and Mexico. For Chile and Peru, the result suggests that export values decrease due to improvements in the quality of ports. Likewise, the correlation between the quality of roads and intraAlliance exports is (negative) reverse for Mexico to Chile, Colombia, and Peru. This result suggests that improvements in the quality of roads reduce exports. Finally, the correlation result between investment as a percentage of GDP and exports from countries of the Pacific Alliance to the rest of 
the world is negative for all countries. It suggests that greater investments in infrastructure decrease exports from the Pacific Alliance countries to the rest of the world.

From a theoretical perspective, the previous analysis shows that the systemic condition of competitiveness is met. In other words, changes in the meso level (infrastructure improvements) have impacts at the micro level (stimulation for the international activity of local market firms). In that sense, another perspective, as proposed by Frischmann (2012) and Kiel et al. (2014), seems to be confirmed. In the same way, according to the theoretical approaches of Khadaroo and Seetanah (2007), Zamora and Pedraza (2013), and Gani (2017), described in the theoretical framework, the improvement of transport infrastructure affects competitiveness because it stimulates international trade given the reduction of transportation times and costs.

\section{CONCLUSIONS AND RECOMMENDATIONS}

A deterioration in export competitiveness can be observed in all Pacific Alliance countries due to a significant increase in costs per container, both for exports and imports. These costs have been significantly affected by the devaluation of each member country's local currency against the United States dollar.

Although Colombia has invested the most in transport infrastructure in the period analyzed, it is nevertheless the Pacific Alliance country with the highest costs, both for exports and imports. Therefore, despite making the most progress in terms of reducing import and export times, Colombia's trade indicators suggest a deterioration in the competitiveness of its exports to the rest of the world. Therefore, there is a strong evidence to reject the null hypothesis that the improvement of transport infrastructure, through increased investment, leads to increased competitiveness.
The opposite is the case of Mexico. Despite having the lowest average investment in transport infrastructure in relation to its GDP, the country has a higher competitiveness of its economy and exports to the rest of the world, in particular because of its geographical proximity to its main US trading partner, its basic connections, the high general quality of its infrastructure, and the ease of multimodal transport. It is the Pacific Alliance member country with the shortest export times, but the third with the highest export costs.

Both Mexico and Chile are member countries of the Pacific Alliance with the highest stock of transport infrastructure, which is the result of heavy investments made by both countries prior to the period under review.

Chile has the highest quality transportation infrastructure within the Pacific Alliance, and is the second most competitive country in terms of export costs. Despite being the third country in growth of its exports, the percentage of investment in its transport infrastructure as a percentage of GDP has decreased. It is therefore suggested that there is a relationship between the development of its transport infrastructure and its competitiveness, with empirical results suggesting a weakening of its competitiveness in the analysis period.

Peru presents a strong evidence of compliance with the null hypothesis. In effect, it is observed that it was one of the most dynamic countries in terms of investment in transport infrastructure; it managed to improve its competitiveness by reducing both time and costs of exports, and had a significant growth in its exports to the rest of the world, as well as to the Pacific Alliance countries.

However, it is important to note that the results of other studies cited above suggest that the achievement of better indicators in terms of competitiveness depends on other significant variables (other than infrastructure investments), such as institutions, concession systems, corruption, macroeconomic impacts (inflation and devaluation), among others. 
On the other hand, the way in which infrastructure investments are financed has an impact on the long-term cost distribution of the project, toll rates, and competitiveness, thus generating both positive and negative externalities for the agents who move freight in each country. Finally, it is evident that PPPs prove to be positive for Latin America, since they share the risk that previously fell solely to the State and create economic incentives that promote efficiency.

\section{REFERENCES}

1. Anderson, J. E., \& van Wicoop, E. (2003). Gravity with Gravitas: A Solution to the Border Puzzle. The American Economic Review, 93(1), 170-192. https://doi.org/10.1257/000282803321455214

2. Asociación para el Fomento de la Infraestructura Nacional. (2012). Plan Nacional de Infraestructura 2012 - 2021. Lima, Peru.

3. Bąk, M. (2016). Transport Development Challenges in the Twenty-First Century. Switzerland: Springer.

4. Bejarano, E. A. (2015). Análisis comparativo de la logística de transporte de carga en Colombia - Bogotá. (Graduate thesis). Universidad Militar Nueva Granada, Bogotá, Colombia. Retrieved from: http://repository.unimilitar.edu.co

5. Benassi, S., Márquez-Ramos, L., Martínez-Zarzoso, I., \& Suárez-Burguet, C. (2015). Relationship between logistics infrastructure and trade: Evidence from Spanish regional exports. Transportation Research Part A: Policy and Practice, 72, 47-61. https://10.1016/j.tra.2014.11.007

6. Çemberci, M., Civelek, M. E., \& Canbolat, N. (2015). The Moderator Effect of Global Competitiveness Index on Dimensions of Logistics Performance Index. Procedia - Social and Behavioral Sciences, 195(3), 1514-1524. https://10.1016/j.sbspro.2015.06.453

7. Chandra, A., \& Thompson, E. (2000). Does public infrastructure affect economic activity?: Evidence from the rural interstate highway system. Regional Science and Urban Economics, 30 (4), 457-490. https:// sites.hks.harvard.edu/fs/achandr/RSUE_InfrastructureEconomicActivity_2000.pdf

8. Consejo Nacional de la Competitividad. (2014). Agenda de Competitividad 2014-2018. Lima, Peru.

9. Coşar, A. K., \& Demir, B. (2016). Domestic road infrastructure and international trade: Evidence from Turkey. Journal of Development Economics, 118, 232-244. https://10.1016/j.jdeveco.2015.10.001

10. Departamento Nacional de Planeación. (2015). Encuesta Nacional de Logística: Resultados Nacionales 2015. Bogotá, Colombia

11. Duranton, G. (2015). Roads and trade in Colombia. Economics of Transportation, 4(1-2), 16-36. http:// dx.doi.org/10.1016/j.ecotra.2014.11.003

12. Fay M., \& Morrison, M. (2007). Infraestructura en América Latina y el Caribe: acontecimientos recientes y desafíos principales. Bogotá, Colombia: World Bank.

13. Frischmann, B. M. (2012). Infrastructure - The Social Value of Shared Resources. New York, United States: Oxford University Press.

14. Flores, J. A. (2015). Infraestructura carretera: construcción, financiamiento y resistencia en Mexico y América Latina. Revista Transporte y Territorio, 13, 122-148. https://doi.org/10.34096/rtt.i13.1880

15. Flores, S. (2017). La identidad internacional de la Alianza del Pacífico. Foreign Affairs Latinoamérica, 17(3), 91-96. https://dialnet.unirioja.es/servlet/articulo?codigo $=6351135$

16. Franco, J. A., Gómez, M. E., \& Becerra, M. A. (2018). Una aproximación al análisis de los sistemas de transporte en Colombia: factor de competitividad. Revista Espacios, 39(47), 1-16. http://www.revistaespacios.com/a18v39n47/18394704.html 
17. Gani, A. (2017). The Logistics Performance Effect in International Trade. The Asian Journal of Shipping and Logistics, 33(4), 279-288. https://10.1016/j.ajs1.2017.12.012

18. Gómez, J., Serna, C., \& Arango, M. (2016). Modelo de evaluación dinámica de la calidad en la infraestructura vial de corredores logísticos en Colombia Revista Escuela de Ingeniería de Antioquia, 13(25), 135-145. https://doi.org/10.24050/reia.v13i25.1022

19. Gutiérrez, J. (2009). Infraestructura Territorial, Economía y Negocios Internacionales en Colombia. Cuadernos de Administración, 42, 97-123. https:/www.researchgate.net/publication/277107608 Infraestructura_Territorial_Economia_y_Negocios_Internacionales_en_Colombia/fulltext/559e2e290 8ae76bed0bb689 d/Infraestructura-Territorial-Economia-y-Negocios-Internacionales-en-Colombia.pdf

20. Gutiérrez, J., Condeço-Melhorado, A., \& Martín, J. C. (2010). Using accessibility indicators and GIS to assess spatial spillovers of transport infrastructure investment. Journal of Transport Geography, 18(1), 141-152. https://doi.org/10.1016/j.jtrangeo.2008.12.003

21. Inter-American Development Bank. (2014). Infraestructura sostenible para la competitividad y el crecimiento inclusivo. Estrategia de infraestructura del BID. Nueva York and Washington DC: Inter-American Development Bank.

22. InvestInPeru. (2016). Infraestructura de Transporte. Retrieved from: http://www.investinperu.pe/modulos/ JER/PlantillaStandard.aspx $?$ are $=0 y$ prf $=0$ yjer $=8006 y s e c=1$

23. Islas, V. M., Hernández, S., \& Blancas, S. (2004). El transporte en la región centro de Mexico. Instituto Mexicano del Transporte. Publicación Técnica No. 232. México D.F, México.

24. Khadaroo, J., \& Seetanah, B. (2007). Transport infrastructure and tourism development. Annals of Tourism Research, 34(4), 1021-1032. https://10.1016/j.annals.2007.05.010

25. Kiel, J., Smith, R., \& Ubbels, B. (2014). The Impact of Transport Investments on Competitiveness. Transportation Research Procedia, 1(1), 77-88. https://doi.org/10.1016/j.trpro.2014.07.009

26. Konings, R., \& Priemus, H. (2014). Terminals and the Competitiveness of Container Barge Transport. Journal of the Transportation Research Board, 2062, 365-371. https://doi.org/10.3141/2062-06

27. Krugman, P. (1994). Competitiveness: A Dangerous Obsession. Foreign Affairs, 73(2), 28-44. https://www. foreignaffairs.com/articles/1994-03-01/competitiveness-dangerous-obsession

28. Laird, J. J., \& Venables, A. J. (2017). Transport investment and economic performance: A framework for project appraisal. Transport Policy, 56, 1-11. https://10.1016/j.tranpol.2017.02.006

29. Legiscomex. (2016). Perfil logístico de Colombia. Retrieved from: https://www.legiscomex.com/BancoMedios/ Documentos\%20PDF/perfil-logistico-colombia-2016-completo.pdf

30. Limão, N., \& Venables, A. (2001). Infrastructure, Geographical Disadvantage, Transport Costs, and Trade. The World Bank Economic Review, 15(3), 451-479. https://www.jstor.org/stable/3990110?seq=1

31. Mačiulis, A., Vasiliauskas, A. V., \& Jakubauskas, G. (2009). The impact of transport on the competitiveness of national economy. Transport, 24(2), 93-99. https://10.3846/1648-4142.2009.24.93-99

32. Manzur, E., Hidalgo, P., Olavarrieta, S., \& Díaz, D. (2006). ¿Sigue siendo Chile un país competitivo? Facultad de Economía y Negocios, Universidad de Chile. 
33. Miranda, A. (2013). Chile en el Asia Pacífico: Las relaciones económicas con Vietnam, Cambodia y Laos en la última década. Santiago de Chile, Chile: Mago.

34. Organization for Economic Cooperation and Development. (2016). OECD Regions at a Glance 2016, OECD Publishing, Paris: France.

35. Organization for Economic Cooperation and Development. (2017). Análisis de gobernanza de infraestructura: Chile. OECD Publishing, Paris: France.

36. Oxford Business Group. (2017). El Peru reconstruye sus infraestructuras de transporte deterioradas. Retrieved from: https://oxfordbusinessgroup.com

37. Plan Nacional de Desarrollo de México. (2012). Plan Nacional de Desarrollo 2013-2018. Mexico D. F.: Mexico.

38. Porter, M. E. (2016). Ser competitivo. 5ª ed. Bogotá, Colombia: Paidós

39. Purwanto, A. J., Heyndrickx, C., Kiel, J., Betancor, O., Socorro, M. P., Hernández, A. (...) \& Fiedler, R. (2017). Impact of Transport Infrastructure on International Competitiveness of Europe. Transportation Research Procedia, 25, 2877-2888. http://dx.doi.org/10.1016/j.trpro.2017.05.273

40. Roda, P., Perdomo, F., \& Sánchez, J. (2015). Impacto de la infraestructura de transporte en el desempeño económico. Bogotá: Departamento Nacional de Planeación, Archivos de Economía, Documento No. 424.

41. Urrunaga, R., \& Bonifaz, J. (2008). Estudios de caso sobre regulación en infraestructura y servicios públicos en el Peru. Lima, Peru: Universidad del Pacífico.

42. Winsor, R.D. (1998). Regional Integration and Competition from a Biogeographic Perspective: An Extension and Elaboration of Organization Ecology. Journal of Competitiveness Studies, 6(1): 30. https://www. questia.com/library/journal/1P3-38371339/regional-integration-and-competition-from-a-biogeographic

43. World Economic Forum [WEF]. (2017). The Global Competitiveness Report 2017-2018. Geneva, Switzerland.

44. Yepes, T., \& Aguilar, J. (2011). Infraestructura para la mayor integración de las Américas. Documento de Trabajo, Fedesarrollo.

45. Zamora, A. I., \& Pedraza, O. H. (2013). El transporte internacional como factor de competitividad en el comercio exterior. Journal of Economics, Finance and Administrative Science, 18(35), 108-118. http://www. scielo.org.pe/scielo.php?pid=S2077-18862013000200007\&script=sci_abstract

46. Zmuda, M. (2017). Towards a Taxonomy of International Competitiveness. Journal of Management and Business Administration. Central Europe, 25(3), 97-116. https://10.7206/jmba.ce.2450-7814.204 


\section{ANNEX 1. CORRELATION TABLES}

\begin{tabular}{|c|c|}
\hline \multicolumn{2}{|c|}{$\begin{array}{c}\text { Investment in Infrastructure as Share of GDP to Time (Days) } \\
\text { to Export in the Pacific Alliance Countries }\end{array}$} \\
\hline Chile & 0.74 \\
\hline Colombia & -0.19 \\
\hline Mexico & -0.14 \\
\hline Peru & -0.38 \\
\hline
\end{tabular}

Quality of Road Infrastructure in the Pacific Alliance Countries to Time (Days) to Export in the Pacific Alliance Countries

\begin{tabular}{|c|c|}
\hline Chile & 0.83 \\
\hline Colombia & -0.15 \\
\hline Mexico & -0.88 \\
\hline Peru & -0.66 \\
\hline
\end{tabular}

Investment in Infrastructure as Share of GDP to Time (Days) to Import in the Pacific Alliance Countries

\begin{tabular}{|c|c|}
\hline Chile & 0.78 \\
\hline Colombia & -0.28 \\
\hline Mexico & -0.10 \\
\hline Peru & -0.45 \\
\hline
\end{tabular}

Quality of Road Infrastructure in the Pacific Alliance Countries to Time (Days) to Import in the Pacific Alliance Countries

\begin{tabular}{|c|c|}
\hline Chile & 0.82 \\
\hline Colombia & -0.18 \\
\hline Mexico & -0.87 \\
\hline Peru & -0.80 \\
\hline
\end{tabular}

Investment in Infrastructure as Share of GDP to Export Cost (US\$ per Container) in the Pacific Alliance Countries

\begin{tabular}{|c|c|}
\hline Chile & -0.69 \\
\hline Colombia & 0.52 \\
\hline Mexico & 0.63 \\
\hline Peru & 0.52 \\
\hline
\end{tabular}

Quality of Road Infrastructure in the Pacific Alliance Countries to Export Cost (US\$ per Container) in the Pacific Alliance Countries

\begin{tabular}{|c|c|}
\hline Chile & -0.61 \\
\hline Colombia & -0.71 \\
\hline Mexico & 0.79 \\
\hline Peru & 0.90 \\
\hline
\end{tabular}

Quality of Road Infrastructure in the Pacific Alliance Countries to Import Cost (US\$ per Container) in the Pacific Alliance Countries

\begin{tabular}{|c|c|}
\hline Chile & -0.57 \\
\hline Colombia & -0.78 \\
\hline Mexico & -0.02 \\
\hline Peru & 0.77 \\
\hline
\end{tabular}

Quality of Port Infrastructure in the Pacific Alliance Countries to Import Cost (US\$ per Container) in the Pacific Alliance Countries

\begin{tabular}{|c|c|}
\hline Chile & 0.09 \\
\hline Colombia & 0.55 \\
\hline Mexico & -0.07 \\
\hline Peru & 0.84 \\
\hline
\end{tabular}

Source: Authors' calculation.

\begin{tabular}{|c|c|}
\hline $\begin{array}{c}\text { Quality of Port Infrastructure in the Pacific Alliance Countries } \\
\text { to Time (Days) to Export in the Pacific Alliance Countries }\end{array}$ \\
\hline Chile & 0.29 \\
\hline Colombia & -0.82 \\
\hline Mexico & -0.92 \\
\hline Peru & -0.89 \\
\hline
\end{tabular}

Quality of Air Infrastructure in the Pacific Alliance Countries to Time (Days) to Export in the Pacific Alliance Countries

\begin{tabular}{|c|c|}
\hline Chile & 0.87 \\
\hline Colombia & 0.83 \\
\hline Mexico & 0.64 \\
\hline Peru & -0.42 \\
\hline
\end{tabular}

Quality of Port Infrastructure in the Pacific Alliance Countries to Time (Days) to Import in the Pacific Alliance Countries

\begin{tabular}{|c|c|}
\hline Chile & 0.27 \\
\hline Colombia & -0.79 \\
\hline Mexico & -0.92 \\
\hline Peru & -0.95 \\
\hline
\end{tabular}

Quality of Air Infrastructure in the Pacific Alliance Countries to Time (Days) to Import in the Pacific Alliance Countries

\begin{tabular}{|c|c|}
\hline Chile & 0.91 \\
\hline Colombia & 0.78 \\
\hline Mexico & 0.67 \\
\hline Peru & -0.56 \\
\hline
\end{tabular}

Quality of Port Infrastructure in the Pacific Alliance Countries to Export Cost (US\$ per Container) in the Pacific Alliance Countries

\begin{tabular}{|c|c|}
\hline Chile & 0.05 \\
\hline Colombia & 0.65 \\
\hline Mexico & 0.79 \\
\hline Peru & 0.86 \\
\hline
\end{tabular}

Quality of Air Infrastructure in the Pacific Alliance Countries to Export Cost (US\$ per Container) in the Pacific Alliance Countries

\begin{tabular}{|c|c|}
\hline Chile & -0.86 \\
\hline Colombia & -0.74 \\
\hline Mexico & -0.58 \\
\hline Peru & 0.63 \\
\hline
\end{tabular}

Investment in Infrastructure as Share of GDP to Import Cost (US\$ per Container) in the Pacific Alliance Countries

\begin{tabular}{|c|c|}
\hline Chile & -0.68 \\
\hline Colombia & 0.47 \\
\hline Mexico & 0.61 \\
\hline Peru & 0.64 \\
\hline
\end{tabular}

Quality of Air Infrastructure in the Pacific Alliance Countries to Import Cost (US\$ per Container) in the Pacific Alliance Countries

\begin{tabular}{|c|c|}
\hline Chile & -0.85 \\
\hline Colombia & -0.71 \\
\hline Mexico & 0.11 \\
\hline Peru & 0.42 \\
\hline
\end{tabular}

